\title{
Selvmord i Norge
}

I desember publiserte Folkehelseinstituttet dødsårsaksstatistikken for 2017: 593 mennesker døde av selvmord i Norge, 403 menn og 190 kvinner. Antallet er litt lavere enn i 2016, men skiller seg ikke mye fra statistikken de siste årene.

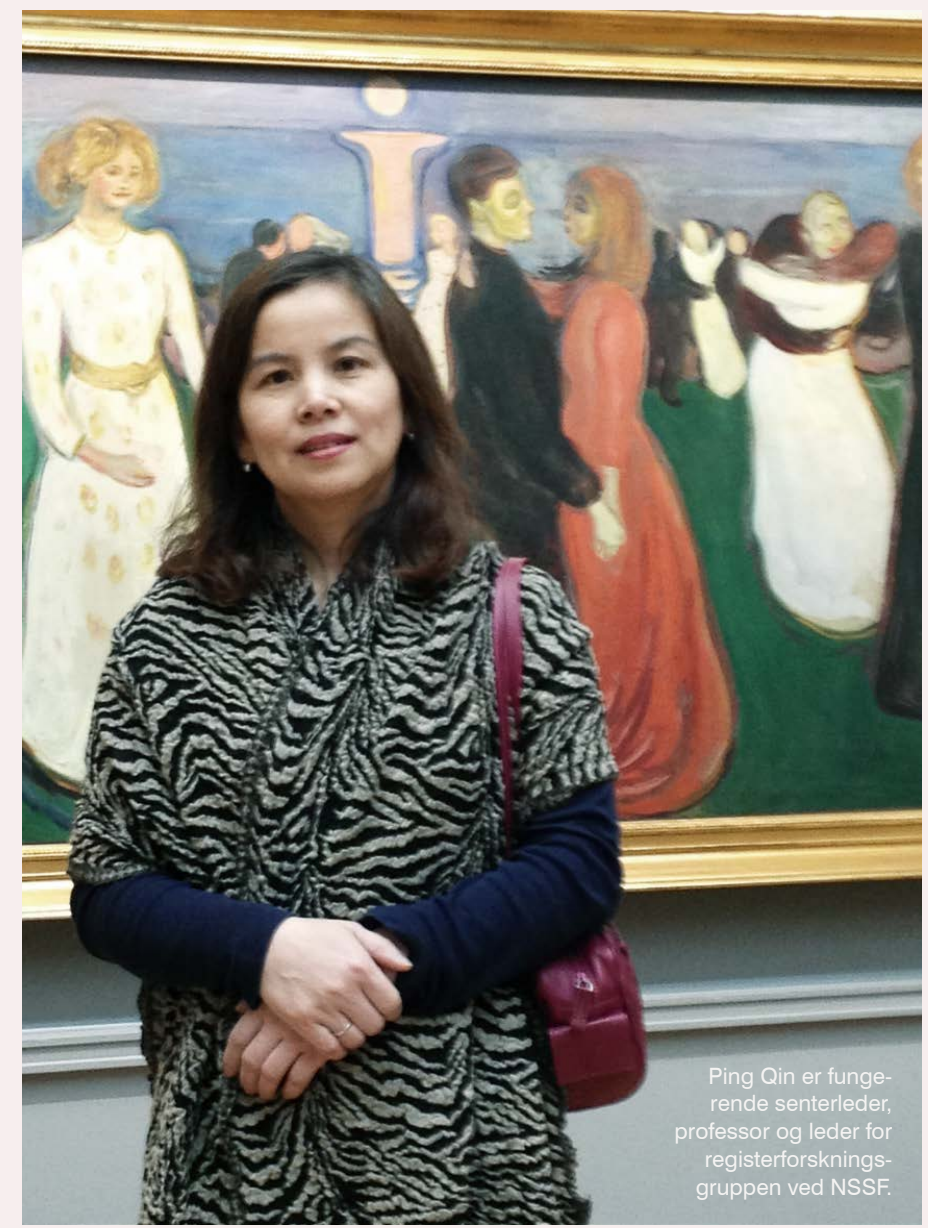

- NÅR JEG STUDERER dataene, ser jeg to viktige endringer som bekymrer meg i høy grad, sier professor Ping Qin som leder registerforskningsgruppen ved NSSF.

\section{Unge liv}

- Den første endringen er at det var 94 selvmord blant unge under 25 år (67 menn og 27 kvinner), 37 under 20 år og 57 i aldersgruppen 20-24 - et høyt antall som vi ikke har sett på mange år.

- Det er trist å se så mange unge mennesker dø ved selvmord i et land som Norge med så mange hielpetilbud. Jeg undres over hva som har skjedd i livene deres? Forsøkte de å få hjelp før de besluttet å ta livet sitt? Og hvor mye støtte og hielp var faktisk tilgiengelig for disse ungdommene?

\section{Metode}

Qin forteller at den andre endringen hun observerer er at hengning og kvelning er blitt en mer vanlig selvmordsmetode blant menn, men også blant kvinner:
$45,7 \%$ av alle selvmord skjedde ved denne metoden, og nesten to tredjedeler av selvmordene blant unge under 25 år skjedde ved denne metoden.

- Dataene fra de siste årene viser en tydelig tendens til at selvmord ved denne metoden har blitt mer vanlig, og dette innebærer en stor utfordring for selvmords-

Det er trist å se så mange unge mennesker do ved selvmord $i$ et land som Norge med så mange hjelpetilbud. forebygging. Tilgangsbegrensning til metoder som legemidler og hotspots har vist seg å være effektivt for selvmordsforebygging, mens materialer som kan brukes til hengning og kvelning er vanskeligere å begrense.

- Selv om vi ikke kan trekke noen konkrete slut-

ninger, tyder tallene på at vi bør observere utviklingen nøye for å drive god forebygging i årene som kommer, avslutter professor Qin. 